\title{
PENGARUH KOMPETENSI DAN SISTEM AKUNTANSI TERHADAP KUALITAS PERTANGGUNGJAWABAN LAPORAN KEUANGAN PADA SATUAN KERJA DI LINGKUNGAN KANWIL KEMENTERIAN AGAMA PROVINSI RIAU
}

\author{
Fadilah Hazrita $^{1 *}$, M. Rasuli ${ }^{2}$, dan Kamaliah ${ }^{2}$ \\ ${ }^{1}$ Program Studi Magister Akuntansi Pasaca Sarjana Universitas Riau \\ ${ }^{2}$ Fakultas Ekonomi Universitas Riau
}

\begin{abstract}
This study aims to determine whether there are significant competence and Accounting System Institution (SAI) to the quality of financial reporting responsibilities on the Kanwil Kementerian Agama Provinsi Riau. Data obtained through census method by distributing questionnaires to the work unit in the Religious Affairs Ministry Riau Province. number of respondents were sent a questionnaire in this study amounted to 66 people. Questionnaire developed and can be obtained further numbered 66. This study uses multiple linear regression. The results showed that competence does not affect the quality of financial reporting responsibilities, while the accounting system institution (SAI) affects the quality of financial reporting responsibilities.
\end{abstract}

Keywords: Competence, Institution Accounting System, the quality of financial reporting responsibilities

\section{PENDAHULUAN}

Laporan pertanggungjawaban merupakan salah satu sumber informasi yang sering digunakan oleh para pengguna laporan pertanggungjawaban. Didalamnya terkandung informasi yang dapat memberikan bahan pertimbangan bagi para pengguna laporan pertanggungjawaban dalam rangka pengambilan keputusan. Manfaat dari kandungan informasi yang ada dalam laporan pertanggungjawaban akan makin berkurang seiring dengan berjalannya waktu. Oleh karena itu ketepatan waktu penyampaian laporan pertanggungjawaban sangatlah penting. Apabila penyelesaian penyajian laporan pertanggungjawaban terlambat atau tidak diperoleh saat dibutuhkan, maka relevansi dan manfaat laporan pertanggungjawaban untuk pengambilan keputusan akan berkurang (Mamduh, 2003:35).

Laporan keuangan kementerian/lembaga adalah bentuk pertanggung jawaban atas pelaksanaan APBN berupa Laporan Realisasi Anggaran (LRA), Neraca dan Catatan atas Laporan Keuangan (CaLK). Keandalan laporan keuangan yang dihasilkan oleh satuan kerja (satker) dengan proses rekonsiliasi. Rekonsiliasi adalah proses pencocokan data transaksi keuangan yang diproses dengan sistem/sub sistem yang berbeda berdasarkan dokumen sumber yang sama. Rekonsiliasi merupakan salah satu kunci utama dalam penyusunan laporan keuangan yang kredibel. Hal ini karena perannya dalam meminimalisasi 
terjadinya perbedaan pencatatan, sehingga berdampak pada validitas dan akurasi data yang disajikan dalam laporan keuangan. ADK (Arsip Data Komputer) merupakan hasil pemprosesan Buku Besar Sistem Akuntansi Instansi (SAI) yang dikirim oleh satker ke KPPN untuk rekonsiliasi dengan data SAU KPPN. Sedangkan satker dinyatakan telah melakukan rekonsiliasi dengan KPPN apabila hasil rekonsiliasi tersebut sudah menunjukkan kesesuaian data dan telah dituangkan dalam Berita Acara Rekonsiliasi.

Sehubungan dengan hal tersebut, diperlukan kompetensi khususnya Sumber Daya Manusia (SDM) yang berkualitas. Kompetensi adalah karakteristik seseorang yang berkaitan dengan kinerja efektif dan atau unggul dalam situasi pekerjaan tertentu. Kompetensi dikatakan sebagai karakteristik dasar (underlying characteristic) karena karakteristik individu merupakan bagian yang mendalam dan melekat pada kepribadian seseorang yang dapat dipergunakan untuk memprediksi berbagai situasi pekerjaan tertentu. Kemudian dikatakan berkaitan antara perilaku dan kinerja karena kompetensi menyebabkan atau dapat memprediksi perilaku dan kinerja.

Sejalan dengan perkembangan kualitas Sumber Daya Manusia (SDM) di bidang ketenagakerjaan, kebutuhan akan tenaga kerja yang mempunyai produktivitas tinggi diperlukan bagi semua pihak, baik lembaga swasta maupun instansi pemerintahan. Hal ini disebabkan peran SDM sangat berpengaruh terhadap keberhasilan pelaksanaan pekerjaan, di mana SDM yang kompeten merupakan salah satu aset penting bagi lembaga untuk mencapai sasaran yang diinginkan. Sehubungan dengan hal tersebut, Satker di Lingkungan Kanwil Kementerian Agama Provinsi Riau dalam hal kompetensi pegawai kebanyakan memiliki latar belakang pendidikan di luar Ekonomi khususnya akuntansi. Sebagian besar pengelola keuangan Satker di Lingkungan Kanwil Kementerian Agama Provinsi Riau berlatar belakang di bidang pendidikan dan bidang agama. Hal ini tentunya akan berpengaruh terhadap kualitas pertanggungjawaban laporan keuangan yang disajikan, karena sebaiknya pertanggungjawaban laporan keuangan seharusnya dibuat oleh orang yang berkompeten di bidang ekonomi khususnya akuntansi.

Selain kompetensi, hal yang juga berhubungan dengan kualitas pertanggungjawaban laporan keuangan adalah Sistem Akuntansi Instansi (SAI). Sistem Akuntansi Instansi (SAI) adalah serangkaian prosedur manual maupun yang terkomputerisasi mulai dari pengumpulan data, pencatatan, pengikhtisaran sampai dengan pelaporan posisi keuangan dan operasi keuangan pada Kementerian Negara/Lembaga. Pentingnya SAI dalam membuat laporan keuangan instansi, diharapkan setiap instansi pemerintah dan tidak terkecuali bagi satker di Lingkungan Kanwil Kementerian Agama Provinsi Riau untuk menyelenggarakan SAI sebagai sistem akuntansi guna menyampaikan laporan keuangan instansi kepada Kantor Pelayanan Perbendaharaan Negara (KPPN). Hal ini sesuai dengan Peraturan Pemerintah Nomor o8 Tahun 2006 Tentang 
Pelaporan Keuangan dan Kinerja Instansi Pemerintah.

Untuk mewujudkan Laporan Keuangan Pemerintah Pusat (LKPP) yang akuntabel sesuai dengan Undang-Undang Nomor 1 tahun 2004 tentang Perbendaharaan Negara jucto Peraturan Pemerintah Nomor 8 Tahun 2006, pada pasal 33 dinyatakan bahwa sistem Pengendalian Internal yang andal harus diciptakan prosedur rekonsiliasi antara transaksi keuangan yang diakuntansikan oleh Pengguna Anggaran/Kuasa Pengguna Anggaran dengan data transaksi keuangan yang diakuntansikan oleh Bendahara Umum Negara/ Daerah, maka pemerintah pusat menyusun suatau sistem akuntansi dan pelaporan keuangan pemerintah dengan mengeluarkan Peraturan Menteri Keuangan Nomor: 171/PMK.05/2007 tanggal 27 Desember 2007 tentang Sistem Akuntansi dan Pelaporan Keuangan Pemerintah Pusat (SAPP), yang di dalamnya antara lain dijelaskan secara rinci bahwa penyusunan LKPP harus melalui proses verifikasi dan rekonsiliasi secara berjenjang dan berkelanjutan. Berdasarkan Peraturan Menteri Keuangan Nomor: PMK-171/PMK.05/2007 bahwa setiap satuan kerja sebagai pengguna anggaran wajib menyelenggarakan SAI untuk menghasilkan laporan keuangan, untuk kemudian setiap bulannya disampaikan ke Kantor Pelayanan Perbendaharaan Negara (KPPN) untuk dilakukan rekonsiliasi (Sijabat: 2010).

Hakikat dan fungsi rekonsiliasi adalah pencocokan data antara dua pihak yang terpisah dengan maksud untuk meningkatkan keandalan laporan keuangan masing-masing pihak. Secara keseluruhan bahwa implementasi di satker di Lingkungan Kanwil Kementerian Agama Provinsi Riau telah dan akan menuju pada keandalan laporan keuangan. Implementasi pada satker di Lingkungan Kanwil Kementerian Agama Provinsi Riau selama ini sudah berjalan dengan baik, tetapi masih ada kendala. Masih terdapat beberapa satuan kerja (satker) sebagai pengguna anggaran, sering terlambat dalam menyampaikan laporan keuangan oleh satker ke KPPN dan UAPPA-W, karena dipengaruhi oleh SDM sehingga kurang efektif dan efisien. Berdasarkan identifikasi kendala di atas, Sistem Akuntansi Instansi saat ini sangat besar pengaruhnya terhadap laporan keuangan, karena sanksi keterlambatan penyampaian laporan keuangan bagi instansi dapat berdampak buruk bagi kinerja instansi di masa mendatang.

Pengaruh kinerja yang dimaksud adalah apabila Kuasa Pengguna Anggaran yakni satker tidak menyampaikan laporan keuangan tersebut, KPPN dapat menunda penerbitan Surat Perintah Pencairan Dana (SP2D) atas Surat Perintah Membayar (SPM) yang diajukan oleh Satker. Prestasi dalam penyampaian laporan keuangan yang menyangkut ketepatan waktu dan keakuratan data dengan menyertakan hasil rekonsiliasi (pencocokan SAI dan SAU) dan Berita Acara Rekonsiliasi (BAR) dari KKPN.

Dalam penelitian ini, parameter dari Sistem Akuntansi Instansi yang digunakan yakni kinerja pekerjaan pengguna SAI dan persepsi manfaat SAI. 
Kinerja pekerjaan pengguna SAI yang dilakukan oleh satuan kerja mempengaruhi keberhasilan seseorang pemakai sistem akuntansi dalam pelaksanaan kerja yang melibatkan penggunaan SAI. Hal ini disebabkan karena setiap instansi menggunakan SAI sebagai sarana/sistem untuk menghasilkan laporan keuangan. Untuk dapat menguasai pengoperasionalan sistem akuntansi tersebut setiap pegawai harus mempunyai kinerja yang baik dalam menggunakan SAI. Dengan kinerja pekerjaan pengguna SAI yang baik maka diharapkan pertanggungjawaban laporan keuangan dapat meningkat dan berkualitas.

Penelitian ini terdorong karena adanya perbedaan hasil penelitian terdahulu tentang kualitas pertanggungjawaban laporan keuangan, khususnya pada satker di lingkungan Kanwil Kementerian Agama Provinsi Riau. Selain itu, bukti hasil audit BPK-RI terhadap kualitas LKPP khususnya Kementerian Agama selama tahun 2004 s.d 2008 yang selalu mendapat opini disclaimer (tidak memberikan pendapat). Penelitian ini merupakan replikasi dari penelitian Amin (2010). Perbedaan penelitian ini dengan penelitian Amin (2010) adalah terletak pada sampel penelitian dan tahun penelitian. Penelitian ini menggunakan sampel Satker di Lingkungan Kanwil Kementerian Agama Provinsi Riau. Hal ini bertujuan untuk mendapatkan cakupan hasil yang lebih luas. Periode amatan yang digunakan yakni tahun 2009-2011. Diharapkan dengan digunakannya data terbaru ini dapat memberikan informasi yang jelas dan aktual sehubungan dengan penelitian ini.

\section{LANDASAN TEORI}

Laporan keuangan kementerian/ kelembagaan adalah suatu hasil dari proses pengidentifikasian, pengukuran, pencatatan dari transaksi ekonomi (keuangan) dari entitas akuntansi yang ada dalam suatu kementerian/kelembagaan yang dijadikan sebagai informasi dalam rangka pertanggungjawaban pengelolaan keuangan entitas akuntansi dan pengambilan keputusan ekonomi oleh pihak-pihak yang memerlukannya. Laporan keuangan kementerian/kelembagaan tersebut harus disusun sesuai dengan Standar Akuntansi Pemerintahan. Yang dimaksud dengan transaksi ekonomi adalah aktivitas yang berhubungan dengan uang sedangkan yang dimaksud dengan pengukuran transaksi ekonomi yaitu dengan menggunakan satuan uang.

Laporan keuangan yang berkualitas harus memiliki karakteristik sebagai berikut (SAP 2010:36):

\section{Relevan}

Laporan keuangan bisa dikatakan relevan apabila informasi yang termuat di dalamnya dapat mempengaruhi keputusan pengguna dengan membantu mereka mengevaluasi peristiwa masa lalu atau masa kini, dan memprediksi masa depan, serta menegaskan atau mengoreksi hasil evaluasi mereka di masa lalu. Dengan 
demikian, informasi laporan keuangan yang relevan dapat dihubungkan dengan maksud penggunaannya. Informasi yang relevan:

a. Memiliki manfaat umpan balik (feedback value), yakni informasi memungkinkan pengguna untuk menegaskan atau mengoreksi ekspektasi mereka di masa lalu;

b. Memiliki manfaat prediktif (predictive value), yakni informasi dapat membantu pengguna untuk memprediksi masa yang akan datang berdasarkan hasil masa lalu dan kejadian masa kini;

c. Tepat waktu, yakni informasi disajikan tepat waktu sehingga dapat berpengaruh dan berguna dalam pengambilan keputusan;

d. Lengkap, yakni informasi akuntansi keuangan pemerintah disajikan selengkap mungkin, mencakup semua informasi akuntansi yang dapat mempengaruhi pengambilan keputusan dengan memperhatikan kendala yang ada. Informasi yang melatarbelakangi setiap butir informasi utama yang termuat dalam laporan keuangan diungkapkan dengan jelas agar kekeliruan dalam penggunaan informasi tersebut dapat dicegah.

2. Andal

Informasi dalam laporan keuangan bebas dari pengertian yang menyesatkan dan kesalahan material, menyajikan setiap fakta secara jujur, serta dapat diverifikasi. Informasi mungkin relevan, tetapi jika hakikat atau penyajiannya tidak dapat diandalkan maka penggunaan informasi tersebut secara potensial dapat menyesatkan. Informasi yang andal memenuhi karakteristik:

a. Penyajian jujur, informasi menggambarkan dengan jujur transaksi seta peristiwa lainnya yang seharusnya disajikan atau yang secara wajar dapat diharapkan untuk disajikan;

b. Dapat diverifikasi (verifiability), informasi yang disajikan dalam laporan keuangan dapat diuji, dan apabila pengujian dilakukan lebih dari sekali oleh pihak yang berbeda, hasilnya tetap menunjukkan simpulan yang tidak berbeda jauh;

c. Netralitas, informasi diarahkan pada kebutuhan umum dan tidak berpihak pada kebutuhan pihak tertentu.

3. Dapat dibandingkan

Informasi yang termuat dalam laporan keuangan akan lebih berguna jika dapat dibandingkan dengan laporan keuangan periode sebelumnya atau laporan keuangan entitas pelaporan lain pada umunya. Perbandingan dapat dilakukan secara internal dan eksternal. Perbandingan secara internal dapat dilakukan bila suatu entitas menerapkan kebijakan akuntansi yang sama dari tahun ke tahun. Perbandingan secara eksternal dapat dilakukan bila entitas 
yang diperbandingkan menerapkan kebijakan akuntansi yang sama. Apabila entitas pemerintah menerapkan kebijakan akuntansi yang lebih baik daripada kebijakan akuntansi yang sekarang diterapkan, perubahan tersebut diungkapkan pada periode terjadinya perubahan.

4. Dapat dipahami

Informasi yang disajikan dalam laporan keuangan dapat dipahami oleh pengguna dan dinyatakan dalam bentuk serta istilah yang disesuaikan dengan batas pemahaman para pengguna. Untuk itu, pengguna diasumsikan memiliki pengetahuan yang memadai atas kegiatan dan lingkungan operasi entitas pelaporan, serta adanya kemauan pengguna untuk mempelajari informasi yang dimaksud.

Kompetensi dimaknai sebagai pengetahuan, keterampilan, dan nilai-nilai dasar yang direfleksikan dalam kebiasaan berfikir, dan bertindak. Kompetensi dapat pula dimaksudkan sebagai kemampuan melaksanakan tugas yang diperoleh melalui pendidikan dan/atau latihan.

Dari definisi di atas dapat disimpulkan bahwa model kompetensi merupakan alat yang digunakan sebagai panduan oleh organisasi yang menggunakan pendekatan kompetensi dalam manajemen SDM-nya. Di mana, model kompetensi itu berisi deskripsi kompetensi-kompetensi yang diperlukan dalam tiap-tiap jabatan di dalam organisasi tersebut. Model kompetensi yang disusun dapat digunakan sebagai dasar dari perencanaan sumber daya manusia, di mana organisasi dapat mendefinisikan dan mengaplikasikan pengetahuan, pelatihan, keterampilan, dan pengalaman.

Sistem Akuntasi Instansi merupakan serangkaian prosedur manual maupun yang terkomputerisasi mulai dari pengumpulan data, pencatatan, pengikhtisaran sampai dengan dengan pelaporan posisi keuangan dan operasi keuangan pada kementerian/lembaga. SAI terdiri dari Sistem Akuntansi Keuangan (SAK), Siistem Informasi Manajemen dan Akuntansi Barang Milik Negara (SIMAK-BMN).

Dalam penelitian ini, Indikator yang digunakan untuk mengukur Sistem Akuntansi Instansi Kinerja Pekerjaan Pengguna SAI dan Persepsi Manfaat SAI. Kinerja pekerjaan pengguna SAI yang dilakukan oleh satuan kerja mempengaruhi keberhasilan seseorang pemakai sistem akuntansi dalam pelaksanaan kerja yang melibatkan penggunaan SAI. Hal ini disebabkan karena setiap instansi menggunakan SAI untuk sarana/sistem dalam menghasilkan laporan keuangan yang berkualitas.

Untuk dapat menguasai pengoperasionalan sistem akuntansi tersebut setiap pegawai harus mempunyai kinerja yang baik dalam menggunakan SAI. Dengan kinerja pekerjaan pengguna SAI yang baik maka diharapkan pertanggungjawaban laporan keuangan dapat meningkat. 
Sistem Akuntansi Instansi merupakan prosedur akuntansi yang dilaksanakan sebagai Pertanggungjawaban Keuangan pada Kementerian Negara/Lembaga. SAI diukur dengan kualitas sistemnya. Sistem akuntansi instansi sudah terkomputerisasi, sehingga tinggal pemahaman. Sistem akuntansi yang memiliki kualitas yang baik diharapkan dapat meningkatkan pertanggungjawaban laporan keuangan. Salah satu cara untuk menentukan kualitas suatu SAI adalah dengan mengukur kualitas informasi yang dihasilkan oleh suatu sistem akuntansi formal. Definisi kualitas SAI mengacu pada tingkat di mana seseorang pemakai sistem akuntansi merasa terpuaskan oleh output (informasi) yang dihasilkan oleh suatu sistem informasi formal.

Sedangkan persepsi manfaat SAI merupakan sikap yang akan mempengaruhi perilaku (behaviour) seseorang termasuk kinerja seseorang yang menggunakan Sistem Akuntansi Instansi. Persepsi kegunaan sistem akuntansi yang dimaksud adalah tingkat di mana seseorang yakin bahwa menggunakan SAI akan meningkatkan pertanggungjawaban laporan keuangan. Apabila seseorang menganggap bahwa SAI yang ada bermanfaat bagi pertanggungjawaban laporan keuangan, maka hal ini akan mempengaruhi perilakunya untuk menggunakan SAI yang ada, akan tetapi sebaliknya apabila dia menganggap bahwa SAI yang ada tidak ada gunanya, maka dia tidak akan menggunakan SAI tersebut.

\section{METODOLOGI}

Populasi dalam penelitian ini adalah Pegawai Keuangan Satker di Lingkungan Kanwil Kementerian Agama Provinsi Riau yang berjumlah 82 orang. Sampel dalam penelitian ini menggunakan metode sensus karena menggunakan seluruh elemen populasi atau disebut juga sampel jenuh.

Data yang digunakan dalam penelitian ini adalah data primer. Data primer merupakan sumber data penelitian yang diperoleh secara langsung dari sumber asli (tidak melalui perantara) (Indriantoro: 2002).

Dalam penelitian ini terdapat dua variabel penelitian yaitu variabel independen dan variabel dependen. Variabel dependen adalah tipe variabel yang dijelaskan atau dipengaruhi oleh variabel independen. Sedangkan Variabel independen merupakan tipe variabel yang menjelaskan atau mempengaruhi variabel lain.

1. Variabel dependen

Variabel dependen yang digunakan dalam penelitian ini adalah kualitas pertanggungjawaban laporan keuangan. Indikator yang digunakan untuk menilai kualitas pertanggungjawaban laporan keuangan antara lain: relevan, andal, dapat dibandingkan, dan dapat dipahami (SAP 2010). 
2. Variabel independen

Variable independen yang digunakan dalam penelitian ini terdiri dari kompetensi dan Sistem Akuntansi Instansi. Indikator yang digunakan untuk menilai kompetensi yakni: pengetahuan, pelatihan, keterampilan, dan pengalaman. Indikator yang digunakan untuk menilai sistem akuntansi instansi yakni kinerja pekerjaan pengguna SAI dan persepsi manfaat SAI.

Lokasi penelitian ini adalah Satker di Lingkungan Kanwil Kementerian Agama Provinsi Riau dengan periode amatan penelitian dari tahun 2009-2011.

Model analisis data yang digunakan untuk menguji hipotesis pada penelitian ini adalah regresi linier berganda (Multiple Regression Analysis) dengan persamaan sebagai berikut:

$$
\mathrm{Y}=\mathrm{a}+\mathrm{b}_{1} \mathrm{X}_{1}+\mathrm{b}_{2} \mathrm{X}_{2}+\mathrm{e}
$$

Dimana:

Y : Kualitas Pertanggungjawaban Laporan Keuangan

a : konstanta

b : koefisien

$\mathrm{X} 1 \quad$ : Kompetensi

X2 : Sistem Akuntansi Instansi

$e \quad$ : pengganggu

\section{HASIL PENELITIAN DAN PEMBAHASAN}

\section{Kualitas Data}

Pengujian validitas menggunakan Kaiser Meyer Olkin (KMO) yang bertujuan untuk mengetahui apakah semua data yang telah terambil telah cukup untuk difaktorkan. Hasil pengujian reliabilitas menunjukkan tidak ada koefisien cronbach alpha yang kurang dari o,6. Sehingga instrumen tersebut reliabel untuk digunakan. Dalam penelitian ini, distribusi normal dapat dilihat dari normal probability plot. Jika data menyebar sekitar garis diagonal, maka model regresi memenuhi asumsi normalitas (Ghozali, 2006).

Hasil uji multikolinearitas dalam penelitian ini dapat disimpulkan bahwa antara variabel independen tidak terjadi persoalan multikolinearitas dan layak digunakan.

\section{Pengujian Hipotesis dan Pembahasan}

Untuk menguji hipotesis-hipotesis dalam penelitian ini digunakan analisis regresi berganda dengan bantuan software SPSS versi 17.0. Keseluruhan hipotesis yang diuji ada tiga. Pengujian seluruh hipotesis menggunakan uji 
regresi berganda (multiple regression). Tujuannya mengetahui pengaruh kompetensi dan Sistem Akuntansi Instansi terhadap kualitas pertanggungjawaban laporan keuangan pada satuan kerja di lingkungan Kanwil Kementerian Agama Provinsi Riau. Hasil analisis regresi terlihat pada Tabel berikut:

Tabel 1: Hasil Analisis Regresi Kualitas Pertanggungjawaban Laporan Keuangan

\begin{tabular}{lrrrrr}
\hline Variable & \multicolumn{2}{c}{ Unstandardized Coefficients } & $\begin{array}{c}\text { Standardized } \\
\text { Coefficients }\end{array}$ & T & \multirow{2}{*}{ Sig. } \\
\cline { 2 - 4 } & \multicolumn{1}{c}{$\mathrm{B}$} & Std. Error & Beta & & \\
\hline (Constant) & 10.811 & 2.640 & & 4.095 & .0002 \\
KPT & .098 & .098 & .102 & 1.004 & .319 \\
SAI & 1.102 & 1.102 & .675 & 6.674 & .000 \\
\hline
\end{tabular}

Persamaan Regresi adalah sebagai berikut:

$\mathrm{Y}=10.811+0.098 \mathrm{X}_{1}+1.1027 \mathrm{X}_{2}$

Keterangan:

$\mathrm{Y}=$ Kualitas Pertanggungjawaban Laporan Keuangan

$\mathrm{X} 1 \quad=$ Kompetensi

$\mathrm{X} 2=$ Sistem Akuntansi Instansi

Persamaan regresi tersebut di atas dapat dijelaskan sebagai berikut:

1. Konstanta sebesar 10.811: artinya jika kompetensi dan sistem akuntansi instansi nilainya adalah 0.000 , maka kualitas pertanggungjawaban laporan keuangan (Y) nilainya adalah 10.811.

2. Koefisien regresi variabel kompetensi $\left(\mathrm{X}_{1}\right)$ sebesar 0.098: artinya jika variabel independen lain nilainya tetap dan variabel kompetensi naik $1 \%$ maka kualitas pertanggungjawaban laporan keuangan (Y) akan mengalami peningkatan sebesar 0.098. Koefisien bernilai positif, artinya terjadi hubungan positif antara kompetensi dengan kualitas pertanggungjawaban laporan keuangan. Jadi, semakin tinggi kompetensi yang dimiliki oleh seseorang, maka semakin meningkat pula kualitas pertanggungjawaban laporan keuangan.

3. Koefisien regresi variabel sistem akuntansi instansi (X2) sebesar 1.102: artinya jika variabel independen lain nilainya tetap dan variabel sistem akuntansi instansi naik 1\% maka kualitas pertanggungjawaban laporan keuangan (Y) akan mengalami peningkatan sebesar 1.102. Koefisien bernilai positif, artinya terjadi hubungan positif antara sistem akuntansi instansi dengan kualitas pertanggungjawaban laporan keuangan. Jadi, semakin tinggi nilai sistem akuntansi instansi, maka semakin meningkat pula kualitas pertanggungjawaban laporan keuangan. 


\section{Pengujian Variabel Secara Parsial (Uji t)}

\section{Variabel Kompetensi}

Berdasarkan hasil pengujian variabel kompetensi pada Tabel IV.12 di atas, variabel kompetensi tidak berpengaruh terhadap kualitas pertanggungjawaban laporan keuangan pada Satker di Lingkungan Kanwil Kementerian Agama Provinsi Riau ( $\mathrm{H}_{1}$ ditolak). Hal ini dibuktikan secara statistik dimana nilai $t_{\text {hitung }}$ (1.004) lebih kecil dibandingkan $t_{\text {tabel }}$ (1.998) dan $\mathrm{P}_{\text {value }}$ lebih besar dari a yakni 0.319 lebih besar dibandingkan dengan 0.05.

\section{Variabel Sistem Akuntansi Instansi}

Berdasarkan hasil pengujian variabel Sistem Akuntansi Instansi secara parsial pada Tabel 1 di atas, menunjukkan bahwa variabel Sistem Akuntansi Instansi berpengaruh terhadap kualitas pertanggungjawaban laporan keuangan pada Satker di Lingkungan Kanwil Kementerian Agama Provinsi Riau $\left(\mathrm{H}_{2}\right.$ diterima). Hal ini dibuktikan secara statistik dimana nilai $t_{\text {hitung }}$ (5.66o) lebih besar dibandingkan $t_{\text {tabel }}$ (1.998) dan $\mathrm{P}_{\text {value lebih kecil dibandingkan dengan } a}$ yakni $0.000<0.05$

\section{PENUTUP}

\section{Kesimpulan}

Tujuan penelitian ini adalah untuk mengetahui pengaruh Kompetensi dan Sistem Akuntansi Instansi (SAI) secara parsial dan bersama-sama (simultan) terhadap Kualitas Pertanggungjawaban Laporan Keuangan pada Satuan Kerja di Lingkungan Kanwil Kementerian Agama Provinsi Riau. Kesimpulan yang diperoleh dari penelitian ini adalah sebagai berikut:

1. Variabel kompetensi tidak berpengaruh terhadap kualitas pertanggungjawaban laporan keuangan pada satuan kerja di lingkungan Kanwil Kementerian Agama Provinsi Riau;

2. Sistem Akuntansi Instansi (SAI) berpengaruh terhadap kualitas pertanggungjawaban laporan keuangan pada satuan kerja di lingkungan Kanwil Kementerian Agama Provinsi Riau;

\section{Keterbatasan}

Keterbatasan penelitian ini antara lain:

1. Hanya menggunakan variabel kompetensi dan Sistem Akuntansi Instansi sebagai faktor-faktor yang mempengaruhi kualitas pertanggungjawaban laporan keuangan, sedangkan masih banyak lagi faktor lain yang mempengaruhi kualitas pertanggungjawaban laporan keuangan, seperti: sistem pengendalian intern, pengorganisasian tim SAI, dan dukungan pimpinan yang belum dimasukkan dalam penelitian ini. 
2. Penggunaan jumlah sampel yang relativ masih sangat sedikit jumlahnya.

\section{Saran}

Berdasarkan kesimpulan hasil penelitian yang telah dikemukakan, dapat diberikan saran-saran yang merupakan sumbangan dari hasil penelitian ini:

a. Bagi peneliti selanjutnya disarankan untuk memasukkan variabel-variabel lainnya yang berpengaruh terhadap kualitas pertanggungjawaban laporan keuangan seperti sistem pengendalian intern, pengorganisasian tim SAI, dan dukungan pimpinan serta disarankan untuk menggunakan sampel yang cakupannya lebih luas, tidak hanya di satu provinsi tetapi seluruh Indonesia, agar didapatkan hasil penelitian yang lebih luas;

b. Bagi peneliti selanjutnya disarankan untuk menambah jumlah sampel penelitian sehingga diperoleh hasil yang lebih akurat dan berkualitas.

\section{DAFTAR PUSTAKA}

Ghozali, Imam. 2006. Aplikasi Analisis Multivariate dengan Program SPSS. Cetakan Keempat. Badan Penerbit Universitas Diponegoro. Semarang.

Indriantoro, Nur dan Bambang Supomo. 2002. Metodologi Penelitian Bisnis. Yogyakarta: Edisi Pertama. Penerbit BPFE.

Mamduh, M. Hanafi. 2004. Manajemen Keuangan. BPFE. Yogyakarta.

Muhardi Agus, Amin. 2010. Pengaruh Kompetensi dan Sistem Akuntansi Instansi Terhadap Kualitas Pertanggungjawaban Laporan Keuangan Pada Unit Pelaksana Teknis (UPT) Kementerian Pendidikan Nasional Provinsi Sumatera Utara. Tesis Universitas Sumatera Utara.

Peraturan Menteri Keuangan No. 171/PMK.o5/2007 tentang Sistem Akuntansi dan Pelaporan Keuangan Pemerintah Pusat.

Peraturan Pemerintah No. 71 Tahun 2010 tentang Standar Akuntansi Pemerintahan.

Peraturan Pemerintah No. 8 Tahun 2006 tentang Pelaporan Keuangan dan Kinerja Instansi Pemerintah.

Undang-Undang Republik Indonesia No. 1 Tahun 2004 tentang Perbendaharaan Negara. 